\title{
Quelques termes relatifs aux puits artésiens
}

\author{
Par Madame Marme LARONDE
}

INGÉNIECR DES ARTS ET MANUFACTURES

\section{Note on the terminology used for artesian wells}

\author{
BY Mrs. IAARONDE
}

NOTE PRELIMINAIRE

En compulsant divers ouvrages d'hydrologie, on constate que les auteurs interprètent différemment la notion de puits artésien. Afin d'éviter tout malentendu qui pourrait éventuellement avoir des conséquences fâcheuses, nous pensons qu'il est utile d'attirer l'attention sur cette divergence d'interprétation et sur la nécessité de bien préciser le sens de ce terme, lorsqu'on l'emploie.

Bien que les puits artésiens aient été en usage depuis la plus haute antiquité, leur nom vient, comme on le sait, de ce qu'ils étaient nombreux dans l'Artois dès le Moyen Age (en en connaît à Lillers en 1126). Nous ignorons à quelle époque ce nom est entré dans l'usage courant. Dans l' «Encyclopédie de Diderot »(1750-1777), les puits artésiens sont encore désignés comme puits forés. Par contre, dans le « Dictionnaire Technologique », édité par 'Thomine à Paris en 1822-1835, on trouve déjà le terme de puits artésien.

Comme, à l'origine, on ignorait la cause qui faisait remonter l'eau dans les puits artèsiens, c'est le fait qu'elle jaillissait qui avait frappé initialement l'imagination des gens et présentait pour eux le plus grand intérêt. En effet, lorsque le niveau de l'eau était loin de la surface du sol et qu'on ne disposait pas encore de moyens de pompage, il fallait aller chercher l'eau souterraine au moyen de galeries à pente douce (par exemple, foggara en Algérie, khettara au Maroc, kiarez en Asie occidentale, kanat
A study of various works on hydrology shows that authors differ in their interpretation of the notion of an artesian well. We think that it might be useful to draw attention to these different interpretations, so as to avoid misunder-

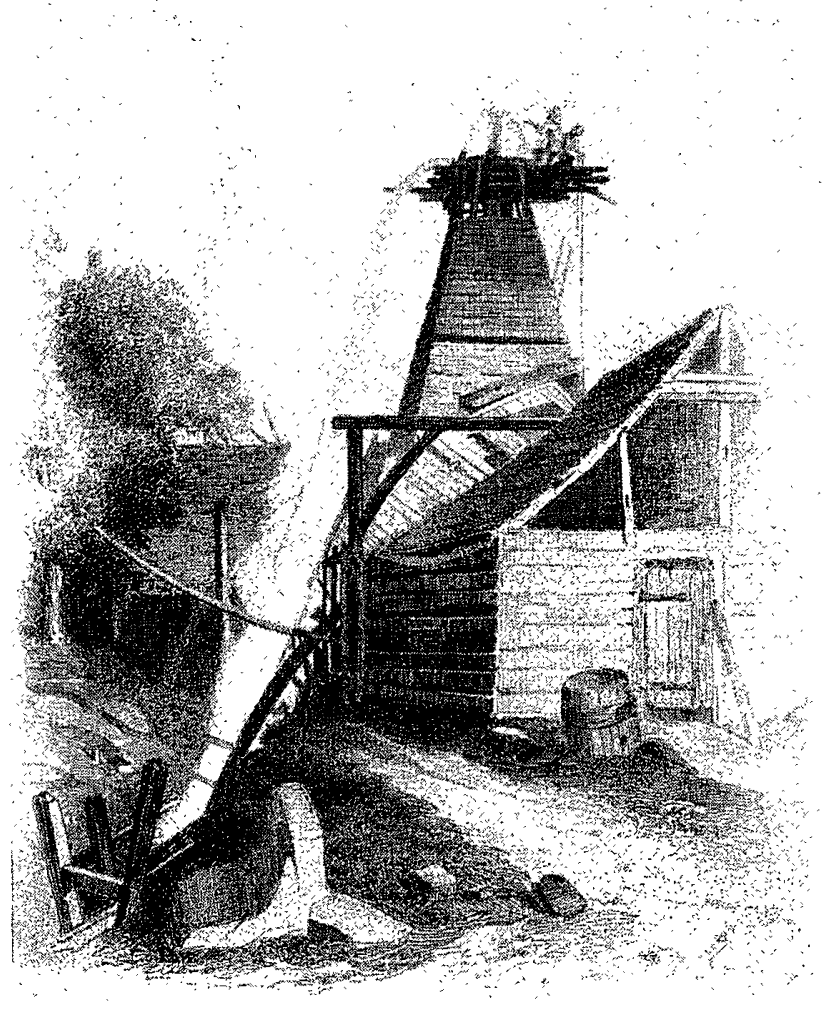


en Iran). C'était un moyen laborieux et coûteux et on comprend l'intérêt que présentaient dans ces conditions les puits jaillissants tels que ceux de l'Artois. Le puits artésien était donc synonyme de puits jaillissant et était défini comme ćtant un puits dont l'eau remonte au-dessus du niveau du sol. Cette définition subsiste encore dans la plupart des ouvrages français et allemands.

Cependant, depuis que l'on sait que les puits artésiens sont alimentés par des nappes captives, on trouve des auteurs (entre autres Daubrée et Imbeaux en France, Höfer von Heimhalt, Keilhack et Prinz en Allemagne, G. A. Waring aux Etats-Unis) qui considèrent qu'un puits artésien n'est pas nécessairement jaillissant, et prennent comme niveau de référence, non celui de la surface du sol, mais celui de la surface inférieure du toit de la nappe captive au droit du puits alimenté. Il semble que cette définition prévaille actuellement en Angleterre, Italie et U.R.S.S.

Enfin on trouve maintenant couramment aux Elats-Unis (Meinzer, Tolman) la définition du puits artésien d'après laquelle c'est un puits dans lequel l'eau remonte à un niveau supérieúr à celui de la surface de la nappe phréatique. Ainsi les trois définitions qu'on donne pour le puits artésien diffèrent par le plan de réfćrence qui peut être :

- la surface du sol,

- la surface intérieure du toit de la nappe captive au droit du puits, et

- la surface de la nappe superficiolle cphréalique) située au-dessus de la nappe alimentant le puits.

Si l'on soumel ces trois définitions à un examen critique, on est conduit, sans doule, à ćcarler la dernière. En effet, tout d'abord elle implique l'existence d'une nappe phréatique, alors que celle-ci pourrait faire défaut, et ensuite il n'est pas judicieux de prendre comme niveau de référence un niveau qui est essentiellement variable et dont la variation n'a, en' général, aucune relation avec celle de la surface piézométrique de la nappe captive (celle-ci ne varie, d'ailleurs, que rarement).

La première définition ne semble pas satisfaisante non plus, car la pression piézométrique de la nappe captive pouvant être, dans certains cas, variable, le même puits pourrait être à certains moments artésien et à d'autres non. En outre, suivant la combinaison du relief $\mathrm{du}$ sol et de la configuration de la surface piézométrique de la nappe captive, les puits alimentés par cette (Suite, p. 924.) standing that might have serious consequences, and to the necessity of defining the precise sense of this term when it is used.

Although artesian wells have been in existence since time inmemorial, they obtained their name from the fact that there were many of them in the Province of Artois as early as in the Middle Ages (one is known to have existed at Lillers as far back as 1126). We are unaware of the date at which the name became widespread. In the " Encyclopédie de Diderot" (1750-1777), artesian wells are still referred to as "puits forés" (bore holes). The "Dictionnaire Technologique" published by Thomine in Paris in 1822-1835 on the other hand already mentions artesian wells as such ("puits artésien ").

Since the factors that caused the water to rise in artesian wells was originally unknown, the thing that appealed to people's imagination and held their interest was the way in which the water gushed out of the earth. Usually, if the underground water level was very deep down, the only way to get at it was - - since no suitable pumps were then in existence - to dig gently sloping galleries (such as foggara in Algeria, khettara in Marocco, kiarez in Western Asia and kanat in Iran). This was a very wearisome and expensive way of getting water and that is why flowing wells i.e, wells from whish flows out above, ground level, like those in the Artois, were the object of such wide interest. The artesian well was thus thought of as synonymous to a flowing well; it was defined as a well in which the water rises above ground level. This definition in still to be found in most of the French and German litlerature on the subject.

However since the discovery that artesian wells are supplied by confined ground water, some authors (e.g. Daubrée and Imbeaux in France, Höfer von Heimhalt, Keilhack and Prinz. in Germany, G.A. Waring in the United States) recognize that an artesian well need not necessarily be one from which water flows out above ground level, and they use the upper surface of the confined ground water in line with the well as a reference level, in preference to the ground level. This definition seems to hold good in Great Britain, Italy and the Soviet Union.

A common definition met in the United States (Meinzer, Tolman) is that by which an artesian well is a well in which the water rises to a level above that of the water table. The three definitions for an artesian well therefore differ in the reference level used; this can be one of the following:

-.- ground level,

(To be continued, p. 924.) 


\begin{tabular}{|c|c|c|c|c|c|}
\hline CONCEPTS & $\begin{array}{l}\text { ALLEMAND } \\
\text { GERMAN }\end{array}$ & $\begin{array}{l}\text { ANGLAIS } \\
\text { ENGLISH }\end{array}$ & $\begin{array}{l}\text { FRANCGAIS } \\
\text { FRENCH }\end{array}$ & $\begin{array}{l}\text { ITALIEN } \\
\text { ITALIAN }\end{array}$ & $\begin{array}{l}\text { RUSSE } \\
\text { RUSSIAN }\end{array}$ \\
\hline $\begin{array}{l}\text { 1. Puits dont l'eau remonte au-dessus du niveau } \\
\text { du sol. } \\
\text { 1) A well, that discharges water at the land sur- } \\
\text { face. }\end{array}$ & $\begin{array}{l}\text { Ueberlaufbrunnen } \\
\text { Springbrunnen }\end{array}$ & Flowing well & Puits jaillissant & $\begin{array}{c}\text { Pozzo zampiìlante } \\
\text { o traboccante }\end{array}$ & $\begin{array}{l}\text { самоиздивающийся } \\
\text { колодец }\end{array}$ \\
\hline $\begin{array}{l}\text { 2. Puits alimenté par une nappe captive et dont } \\
\text { l'eau remonte au-dessus du niveau du sol. } \\
\text { 2) A well that is fed by confined ground water } \\
\text { and which discharges water at the land } \\
\text { surface. }\end{array}$ & $\begin{array}{l}\text { Artesischer } \\
\text { (DIN } 4049 / 1954, \\
\text { Koehne ef la plu- } \\
\text { part des auteurs } \\
\text { allemands) }\end{array}$ & $\begin{array}{l}\text { Artesian flowing } \\
\text { well }\end{array}$ & $\begin{array}{l}\text { Puits artésien jail- } \\
\text { lissant }\end{array}$ & $\begin{array}{l}\text { Po z zo artesiano } \\
\text { zampillante o tra- } \\
\text { boccante }\end{array}$ & $\begin{array}{l}\text { самоизливающи йся } \\
\text { артезианский } \\
\text { колодец }\end{array}$ \\
\hline $\begin{array}{l}\text { 3. Puits alimenté par une nappe captive et dont } \\
\text { l'eau remonte all-dessus de la nappe phréatique. } \\
\text { 3) A well that is fed by confined ground water } \\
\text { and in which the water rises above the water } \\
\text { table. }\end{array}$ & & $\begin{array}{l}\text { Artesian well } \\
\text { (Meinzer, Tolman) }\end{array}$ & & & \\
\hline $\begin{array}{l}\text { 4. Puits alimenté par une nappe captive et dont } \\
\text { leau remonte au-dessus de la surface infé- } \\
\text { rieure du toit de cette nappe. } \\
\text { 4) A well that is fed by confined ground water } \\
\text { and in which the water rises above the upper } \\
\text { surface of the confined ground water. }\end{array}$ & $\begin{array}{l}\text { Artesischer } \\
\text { Brunnen } \\
\text { (Höfer von Heim- } \\
\text { halt, Keilhack) }\end{array}$ & $\begin{array}{l}\text { Confined wa t e r } \\
\text { well (Tolman), } \\
\text { artesian well } \\
\text { (Lee) }\end{array}$ & $\begin{array}{l}\text { Puits artésien } \\
\text { (Imbeaux, Dau- } \\
\text { brée) }\end{array}$ & $\mid \begin{array}{c}\mathrm{Pozzo} \text { artesiano } \\
\text { o modenese }\end{array}$ & $\begin{array}{l}\text { артезианский } \\
\text { колсдец }\end{array}$ \\
\hline $\begin{array}{l}\text { 5. Puits alimenté par une nappe captive et dont } \\
\text { l'eau remonte au-dessus de la surface inferieure } \\
\text { du toit de cette nappe sans atteindre le nivean } \\
\text { du sol. } \\
\text { 5) A well that is fed by confined ground water } \\
\text { and in which the water rises above the upper } \\
\text { surface of the confined ground water without } \\
\text { however reaching ground level. }\end{array}$ & & $\begin{array}{l}\text { Subartesian well } \\
\text { (Meinzer) }\end{array}$ & & $\begin{array}{l}\text { Pozzo artesiano } \\
\text { saliente }\end{array}$ & $\begin{array}{l}\text { несамозлива- } \\
\text { юшийся } \\
\text { артезианскнй } \\
\text { колодец }\end{array}$ \\
\hline $\begin{array}{l}\text { 6. Nappe d'eau souterraine limitée an-dessus par un } \\
\text { toit imperméable ou sensiblement moins per- } \\
\text { méable que la conche aquifére de cette nappe. } \\
\text { 6) Ground water limited above by an impermeable } \\
\text { bed or a bed that is less permeable than that } \\
\text { containing the ground water. }\end{array}$ & $\begin{array}{l}\text { Gespanntes Grund- } \\
\text { wasser } \\
\text { (DIN } 4049 / 1954, \\
\text { Koehne), artesis- } \\
\text { ches Wasser, } \\
\text { Druckwasser } \\
\text { (Keilhack) }\end{array}$ & $\begin{array}{l}\text { Confined } \\
\text { w a t e ro round } \\
\text { w a t e r } \\
\text { Lee) }\end{array}$ & $\begin{array}{c}\text { Na p p e captive; } \\
\text { nappe artésienne }\end{array}$ & F a ld a artesiana; & артезианские воды \\
\hline $\begin{array}{l}\text { 7. Nappe captive dont la surface piezometrique est } \\
\text { au-dessus du niveau du sol. } \\
\text { 7) Confined ground water, the piezometric surface } \\
\text { of which is above ground level. }\end{array}$ & $\begin{array}{l}\text { Artesisches Wasser } \\
\text { (Koehne); arte- } \\
\text { sisches W a s s e r } \\
\text { mit pos i t i ver } \\
\text { Druckfläche } \\
\text { (Keilhack) }\end{array}$ & & & $\begin{array}{l}\text { A c q u e artesiane } \\
\text { zampillanti o tra- } \\
\text { boccanti }\end{array}$ & \\
\hline
\end{tabular}




\begin{tabular}{|c|c|c|c|c|c|}
\hline CONCEPTS & $\begin{array}{l}\text { ALLEMAND } \\
\text { GERMAN }\end{array}$ & $\begin{array}{l}\text { ANGLAIS } \\
\text { ENGLISH }\end{array}$ & $\begin{array}{l}\text { FRANCAIS } \\
\text { FRENCH }\end{array}$ & $\begin{array}{l}\text { TALIEN } \\
\text { TTALIAX }\end{array}$ & $\begin{array}{l}\text { RUSSE } \\
\text { RUSSIAX }\end{array}$ \\
\hline $\begin{array}{l}\text { 8. Nappe captive dont la surface piézométrique est } \\
\text { au-dessous du niveau du sol. } \\
\text { 8) Confined ground water, the piezometric surface } \\
\text { of which is below ground level. }\end{array}$ & $\begin{array}{l}\text { Artesisches Wasser } \\
\text { mit negativer } \\
\text { Druckfläche } \\
\text { (Keilhack) }\end{array}$ & & & $\begin{array}{r}\text { A c q u a artesiane } \\
\text { salienti }\end{array}$ & \\
\hline $\begin{array}{l}\text { 9. Nappe captive dont la surface piézométrique est } \\
\text { au-dessus de la nappe phréatique. } \\
\text { 9) Confined ground water, the piezometric surface } \\
\text { of which is above the water table. }\end{array}$ & & $\begin{array}{l}\text { Artesian water } \\
\text { (Meinzer, Tolman) }\end{array}$ & & & \\
\hline $\begin{array}{l}\text { 10. Nappe captive dont la surface piezométrique est } \\
\text { au-dessous de la surlace de la nappe phréatique. } \\
\text { 10) Confined ground water, the piezometric surface } \\
\text { of which is below the water table. }\end{array}$ & & $\begin{array}{l}\text { Ground water with } \\
\text { subnormal pres- } \\
\text { sure head } \\
\text { (Meinzer) }\end{array}$ & & & \\
\hline $\begin{array}{l}\text { 11. Conche imperméable on sensiblement moins per- } \\
\text { méable que la couche aquifere subjacente com- } \\
\text { prenant une nappe captive. } \\
\text { 11) Impermeable ground stratum or a stratum less } \\
\text { permeable than the underlying stratum con- } \\
\text { taining the confined ground water. }\end{array}$ & Deckschicht & Confining bed & $\begin{array}{l}\text { Toit d'une nappe } \\
\text { captive }\end{array}$ & & \\
\hline $\begin{array}{l}\text { 12. Couche imperméable ou sensiblement moins per- } \\
\text { méable que ia couche aquifere surjacente. } \\
\text { 12) Impermeable ground stratum or a stratum less } \\
\text { permeable than the overlying aquifer. }\end{array}$ & Sohlschicht & & $\begin{array}{l}\text { Mur d'une nappe } \\
\text { souterraine }\end{array}$ & & \\
\hline $\begin{array}{l}\text { 13. Surface limite supérienre d'une nappe captive. } \\
\text { 13) Upper surface of confined ground watcr. }\end{array}$ & $\begin{array}{l}\text { Grundwasserdeck- } \\
\text { fläche }\end{array}$ & & & $\begin{array}{l}\text { Tetto di una falda } \\
\text { artesiana }\end{array}$ & $\begin{array}{l}\text { кровля } \\
\text { артезианского } \\
\text { водоносного } \\
\text { горизонта }\end{array}$ \\
\hline $\begin{array}{l}\text { 14. Surface limite inferrieure d'une nappe souterraine. } \\
\text { 14) Lower surface of ground water. }\end{array}$ & Grundwassersohle & & & $\begin{array}{l}\text { Letto di una falda } \\
\text { accutifera }\end{array}$ & $\begin{array}{l}\text { подошва } \\
\text { водоносного } \\
\text { горизонта }\end{array}$ \\
\hline $\begin{array}{l}\text { 15. Surface imaginaire dont chaque point représente } \\
\text { la hanteur piézométrique de l'eau d'une nappe } \\
\text { sonterraine sur la verticale de ce point. } \\
\text { 15) Imaginary surface of which each point repre- } \\
\text { sents the piezometric head of the ground } \\
\text { water on the vertical line through the point. }\end{array}$ & $\begin{array}{l}\text { Grundwasserdruck- } \\
\text { fläche }\end{array}$ & $\begin{array}{l}\text { Piezometric surface } \\
\text { or pressure sur- } \\
\text { face }\end{array}$ & $\begin{array}{c}\text { Surface piézomé- } \\
\text { trique }\end{array}$ & $\begin{array}{l}\text { Superficie piezo- } \\
\text { metrica }\end{array}$ & $\begin{array}{l}\text { пьезометрическая } \\
\text { или налорная } \\
\text { поверхность }\end{array}$ \\
\hline $\begin{array}{l}\text { 16. Dépression, causée par un puits, de la surface } \\
\text { piézométrique d'une nappe captive. } \\
\text { 16) Depression in the piezometric surface of confin- } \\
\text { ed ground water, due to a well. }\end{array}$ & $\begin{array}{l}\text { Senkungstrichter } \\
\text { der Grundwasser- } \\
\text { druckfläche }\end{array}$ & $\begin{array}{l}\text { Cone of pressure } \\
\text { relief }\end{array}$ & $\begin{array}{l}\text { Cône de dépres- } \\
\text { sion d'une nappe } \\
\text { captive }\end{array}$ & $\begin{array}{l}\text { Imbuto o cono di } \\
\text { depressione della } \\
\text { superficie piezo- } \\
\text { metrica }\end{array}$ & $\begin{array}{l}\text { депрессионная } \\
\text { воронка } \\
\text { артезианских вод }\end{array}$ \\
\hline $\begin{array}{l}\text { 17. Courbe de niveau d'une sturface piézométrique. } \\
\text { 17) Contour of piezometric surface. }\end{array}$ & $\begin{array}{l}\text { Wasserdruck- } \\
\text { schichtlinie }\end{array}$ & Isopiestic line & $\begin{array}{l}\text { Courbe isopiczome- } \\
\text { trique }\end{array}$ & Linea isopiezica & гидроизопьеза \\
\hline
\end{tabular}


nappe seraient, d'après cette définition, les uns artésiens et les autres non, comme, par exemple, les puits 2 et 1 de la figure 1 . Signalons enfin le cas où ún puits traverserait une formation perméable surjacente au toit imperméable de la nappe captive et dont on aurait omis de l'isoler. L'eau du puits s'écoulerait alors dans celte formation perméable surjacente, sans atteindre la surface du sol et, d'après la définition, ne serait pas considéré conme étant artésien. Or,

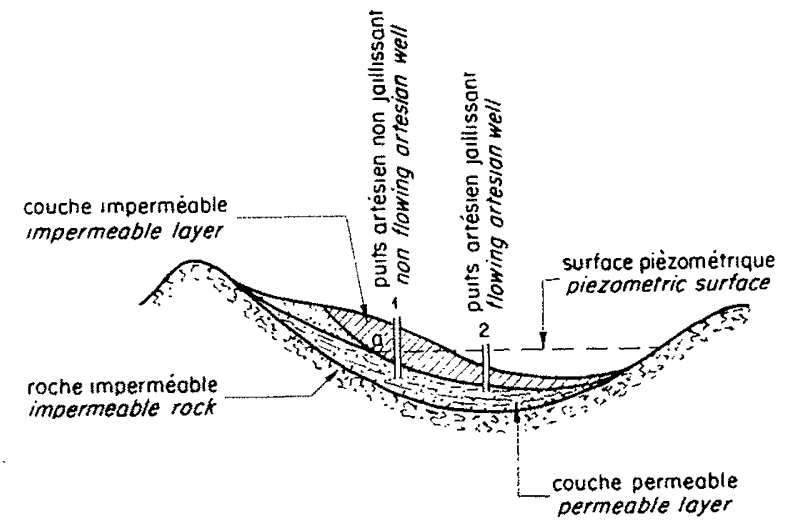

Fig. 1

il est évident qu'un puits alimenté par une nappe captive, qu'il soit jaillissant ou simplement ascendant, est de même nature. La plupart des' auteurs anglais sont de cet avis en cas, car c'est elle qui traduit le mieux la cause du puits artésien et sa caractéristique essentielle, c'est-à-dire qu'il est alimenté par une nappe captive sous pression on attire l'attention sur cette dernière précision, car, bien que les nappes captives soient en général sous pression, il peut $y$ avoir des cas où il n'en est pas ainsi et le puits foré jusqu'à de telles nappes captives ne serait pas artésien, mais aspirant.

Toutefois, même en adoptant la deuxième définition, il y a lieu de remarquer 'qu'on peut être en présence de puits artésiens intermittents, tel que serait, par exemple, le puits 1 de la figure 1. En effet, suivant l'alimentation de la nappe captive, qui dépend des conditions météorologiques, le point $a$, qui détermine la transition entre la nappe libre et la nappe captive, peut se déplacer, en se rapprochant du puits 1 . Le cas échéant, le point $a$ peut dépasser le point où le puits 1 traverse la surface inférieure du toit de la nappe captive et alors il n'est plus artésien. Ce puits 1 serait donc un puits intermittent.

Signalons aussi qu'un puits peut être ascendant, sans être artésien, c'est-à-dire sans être alimenté par une nappe captive. Ce phénomène s'explique par des conditions particulières du gradient de pression. Les figures 2 et 3 en donnent des exemples.
- the upper surface of the confined ground water in line with the rell,

- the water table above the confined ground water from which the well is supplied.

A critical examination of these three definitions should result in the third one of them being discorded. First, it assumes that ground water with a liee surface exists, whereas in actual fact it might not, secondly it is never wise to use an essentially variable level for reference purposes, particularly if the variations occuring are in no way related to the piezometric surface of the confined ground water, which itself seldom varies.

The first definition is not quite satisfactory either, because the piezometric surface of the confined ground water may be variable in some cases, so that the well would be artesian for some of the time and non artesian for the remainder. Furthermore, depending on a combination of the ground profile and the profile of the piezometric surface of the confined ground water, some of the wells supplied from this confined ground water would be artesian and others not, according to the first definition as for instance wells 2 and 1 in the figure 1. Finally, there is the case where a well traverses a permeable layer overlying the upper confining bed of the confined ground water without the necessary precautions having been taken to isolate it. The well water would then seep into the overlying permeable layer without reaching ground level, and the well would not be an artesian well according to the definition. And yet a well that is fed by confined ground water is of the same nature whether the water discharges at ground level or merely rises in the well without reaching the surface. Most british authors seem to agree with this point of view, for they distinguish between "flowing artesian wells" and "nonflowing artesian wells".

The second of these definitions therefore seems to be more suitable in the majority of cases, for it expresses better than the others the cause of an artesian well and its basic characteristic, i.e. that it is fed by confined ground water under pressure. The qualification "under pressure" is important, because although confined ground water usually.is in this state, some instances occur where it is not so, and a well sunk to ground water in this category would be absorbing instead of artesian.

However, even if the second definition is accepted, it should be noted that some artesian wells can be intermittent, as for instance well 1 in the illustration. Depending on the supply to the confined ground water, which varies with 
Outre les trois définitions discutées plus haut, on pourrait en envisager encore d'autres, mais nous nous sommes limités à celles qui sont les plus courantes.

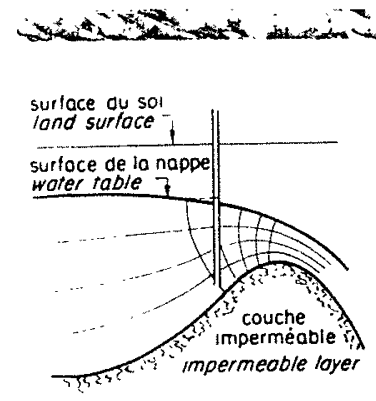

FIG. 2

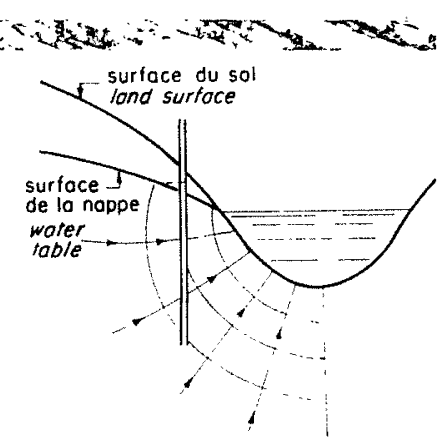

FIG. 3
On avait conclu que la deuxième définition était préférable aux deux autres. Cependant, suivant le point de vue auquel on se place, il peut y avoir des cas où l'une ou l'autre de celles-ci soient plus commodes. L'essentiel, et c'est sur ce point que nous avons voulu attirer l'attention, est de bien préciser la définition adoptée avant d'aborder la question des puits artésiens, afin d'éviter tout malentendu dans sa discussion.

$$
* *
$$

Nous donnons pp. 922-923 un tableau comparatif de quelques termes les plus employés en allemand, anglais, français, italien et russe se rapportant aux puits artésiens. meteorological conditions, point "a", which marks the transition from free to confined ground water can move towards weil 1 . In certain cases, point "a " can move beyond the point where well 1 passes through the confining bed of the confined ground water, so that the well is no longer artesian. Well 1 would therefore be an intermittent well.

It is also pointed out that a well can be rising without being artesian i.e. without being supplied by confined ground water. This phenomenon is due to special conditions of the pressure gradient. Two examples of this are depicted in Figs. 2 and 3.

Other definitions apart from the three mentioned above could be considered, but we have restricted our arguments to those that are most usual.

Although the conclusion was that the second of these definitions was better than the other two, one or the other of these may be more convenient in some cases depending on the angle from which the question is approached. The essential point we have tried to bring into evidence is that the definition that has been chosen must be precisely' stated before artesian wells are discussed, so as to eliminate all likelihood of ambiguity or misunderstanding.

$$
*
$$

See pp. 922-923 a comparative table of the most common terms applied to artesian wells in English, French, German, Italian and Russian.

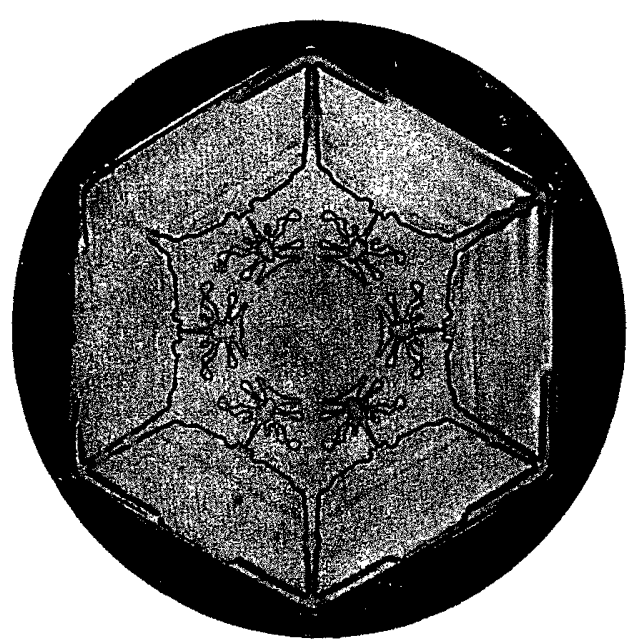

